Kablova Tetiana,

$\mathrm{PhD}$ in Arts, associate professor, Head of chair of Instrumental and Performens

Skills Institute of Arts of

Borys Grinchenko Kyiv University

kablovatania@ukr.net

ORCID 0000-0002-6664-5288

\title{
MUSICAL ETHOS OF THE EPOCH OF MIDDLE AGES
}

The research is aimed at studying the concept of musical ethos, as a characteristic universal in the conditions of the cultural space of the Middle Ages. The mentioned topic forms the following task: to indicate the main aspects of the formation of the concept of ethos of music in the Middle Ages. The methodology of work is to use comparative, historical and logical methods, a hypothetical and deductive method, which suggests the need for the existence of universal concepts in artistic cultural space, where there are certain concepts that are studied in the Middle Ages. Music is considered by the author as a form in which spiritual and real are combined. Scientific novelty. The musical ethos of the Middle Ages is primarily studied from the standpoint of the church, while at the same time not losing its material essence of scientific novelty. In the cultural space, the musical ethos is a spiritual core, a moral and psychological platform, on which the figurative and aesthetic model of contemporary humanity of life and worldview is built up. The musical ethos is characterized as the perfect embodiment of the material musical substrate, in the process of mastering the typical signs of time. Conclusions. The musical ethos is seen as a definite universal notion. It is the musical ethos that embodies the socio-psychological orientation of the world picture and the general mental setting for the formation of the cultural-civilizational process, its ability to generate and cultivate new types of reactions, ideas, and tastes in these forms. Thus, the musical ethos appears to be the genesis for the implementation in artistic forms of the preferences and cultural images.

Key words: ethos; music; artistic forms; cultural space.

Каблова Тетяна Борисівна, кандидат мистецтвознавства, доцент, завідувач кафредри інструментальновиконавської майстерності Інституту мистецтв Київського університету імені Бориса Грінченка

Музичний етос епохи Середньовіччя

Мета. Дослідження спрямоване на вивчення поняття музичного етосу, як характерної універсалії в умовах культуропростору епохи Середньовіччя. Зазначена тема формує наступне завдання: зазначити основні аспекти формування поняття етосу музики в епоху Середньовіччя. Методологія роботи полягає у використанні компаративного, історико-логічного методів, гіпотетико-дедуктивному метод, що дозволяє припустити потребу існування універсальних понять в мистецькому культуропросторі, де існують певні поняття, які вивчаються в епоху Середньовіччя. Музика розглядається автором як фрорма де поєднується духовне та реальне. Музичний етос культури середньовіччя перш за все вивчається з позицій церкви, водночас не втрачаючи своєї матеріальної сутності. Наукова новизна. В культурному просторі музичний етос є духовним стрижнем, морально-психологічною платформою, на котрій вибудовується образно-естетична модель сучасного людству буття та світосприйняття. Музичний етос характеризується як ідеальне втілення матеріального музичного субстрату, в процесі опанування типових ознак часу. Висновки. Музичний етос розглядається як певне універсальне поняття. Саме музичний етос втілює соціо-психологічну орієнтацію картини світу та загальну ментальну установку на формування культуро-цивілізаційного процесу, його здатність генерувати і культивувати нові типи реакцій, уявлень, смаків саме в цих фоормах. Таким чином саме музичний етос постає ґенезою для імплементації у мистецьких формах вподобань та образів культури.

Ключові слова: етос; музика; мистецькі фрорми; культуропростір.

Каблова Татьяна Борисовна, кандидат искусствоведения, доцент, заведущая кафедры инструментальноисполнительского мастерстваь Института искусств Киевского университета имени Бориса Гринченка

Музыкальный этос эпохи Средневековья

Цель. Исследование направлено на изучение понятия музыкального этоса, как характерной универсалии в условиях культурного просторанства эпохи Средневековья. Указанная тема формирует следующее задание: указать основные аспекты формирования понятия этоса музыки в эпоху Средневековья. Методология работы заключается в использовании сравнительного, историко-логического методов, гипотетико-дедуктивный метод, что позволяет предположить необходимость существования универсальных понятий в художественном пространстве культуры, где существуют определенные понятия, изучаемых в эпоху Средневековья. Музыка рассматривается автором как фрорма где сочетается духовное и реальное. Музыкальный этос культуры средневековья прежде всего изучается с позиций церкви, при этом не теряя своей материальной сущности Научная новизна. В культурном пространстве музыкальный этос является духовным стержнем, моральнопсихологической платформой, на которой выстраивается образно-эстетическая модель современного человечеству бытия и мировосприятия. Музыкальный этос характеризуется как идеальное воплощение материального музыкального субстрата, в процессе освоения типичных признаков времени. Выводы. Музыкальный этос рассматривается как некое универсальное понятие. Именно музыкальный этос воплощает социо-психологическую ориентацию картины мира и общую ментальную установку на формирование культур-цивилизационного процесса, его способность генерировать и культивировать новые типы реакций, представлений, вкусов именно в этих формах. Таким образом именно музыкальный этос возникает генезисом для имплементации в художественных формах предпочтений и образов культуры.

Ключевые слова: этос; музыка; художественные формы; пространство культуры.

The main task today is to explain rationally the need to preserve the images of the past culture and to form the representation of this on the modern background . Everything around is aimed at determining the spiritual criteria of human existence. But most clearly this need was formed in the Middle Ages.

The numerical symbolism of music as a science of the antiquity era was found to continue in the Middle Ages. Music embodies the picture of the ideal being, and ethos is the world seen with God's eyes. Undoubtedly, in such an approach the unification of music and its submission to a single principle, the glorification of the Christian church, becomes central. The musical ethos does not carry an independent meaning. It is musically expressed by the will of Lord. And only through this it reflects the highest level of Harmony of the Being. 
The musical ethos of the Middle Ages is primarily studied from the standpoint of the church, and at the same time, without losing its material essence. The emergence of the Gregorian chorale, the domination of the text while underestimating the role of musical accompaniment is bounded with the provision of the allegorical value of music. ALL musical (voice, melody, performance, instrumental) is considered from the standpoint of Christian religion and explains the Divine essence of the world and the incomprehensibility of the Supreme Harmony. A number of medieval music scholars such as Cassidor, Augustine, Thomas Aquinas pointed out that the provision of church religious ideology became central in all existing music. The division of music by Boyce: world music - "music of spheres"; human - interconnection of human soul and body, instrumental - in the sounds of musical instruments. Treatises of Regino with Pruma: Orpheus and Evredique - perfect music and Higher Harmony of the World, natural music and artificial, 9 muses - 9 planets. However, at the same time development of music is considered not as a kind of art, but as a science in the works of M. Herbert, M. Paduansky, Guido from Arezzo, Adam of Fulda. They consider music also from the position of theocentrism and continue to study the aesthetic, catharsic role of music, its direction on achievement of the highest ideals of the human and spiritual harmony.

The spiritual fullness of the song is the movement of the human soul to piety. Ethical rigorism, that is the dependence and subjection of art and music to the laws of morality, forms the basis of musical ethos. Secular music is considered to be corrutive. An unndoubtful advantage have the vocal productions, where the instrumental music serves a seasoning for the word and sound, as pointed out by V. Shestakov. At the same time, the theoretical aspects of music are studied - fixation (Guido from Arezzo), five types of the rhythm according to their perception by person, rhythm and meter, music as a modulating science, from "modus" - measure (Augustine). Also, Augustine continued in his writings the study of the connections of number with structure of the universe and proportionality. More than that, attention was given to the truly ethical in music of the Middle Ages, namely the highest level of communication between music and text in psalms and anthems. An interesting point in the treatises of Cassiodor is the chapter "On the connection of music with religion," where he states that a conceited cannot sing the psalm on restraint. As a result, the spirit of the era is reflected both in the spirit of music and in the personal features of the performer[4].

Boethius continued the mathematical overviews of the musical art. He studied antique works, in particular Aristotle, Euclid, Plato, and greatly influenced the general development of the scientific thought of the Middle Ages. He argues that the theoretical mastering of musical thought is much more important than its practical mechanical execution: "The essence of music is embodied in a certain organization of the mind, as one that is the highest ideal form of being, unlike the physical, material body". Regino with Pruma followed the same idea: "The musician is not the one, who works with his hands, but the one who can logically disribe it".

Therefore, if the ancient tradition connects practical and contemplative, then the Middle Ages introduce contemplative to a higher level. Unfortunately, such an approach did not allow the development of a science of music. On the contrary, before Guido from Arezzo, the named researchers were basic and did not provide particularly vivid enrichments. At this time there is a dissolution of practical performance from the theoretical. Attention is paid to pedagogical issues of vocal performance development . In the musical-pedagogical treatise "Micrologist", Guido from Arezzo denies the mathematical, abstract and numerical approach to music, and puts forward the problems of matching the musical composition to the nationality, temperament, character of the performer. Consequently, Guido from Arezzo not only forms the basis of notation and solmization, he also, together with Odo of Cluny and John Cotton, brings practical music to a separate level of existence. Interestingly, the connection between music and words is studied with all psychological depth, and the demands are ut forward for the compilation of new works and styles of performance according to one or another verbal work and its text.

Hence, in the days of Antiquity and the Middle Ages, the doctrine on music provides opportunities to bring the concept of musical ethos as a certain substance, which obtains materially-perfect manifestation in real musical works or sounds. This binary nature is guaranteed by the very specificity of musical (spatial) art, where any work is a fixed image of the sound substrate. This causes the necessity for the further features of this concept.

Socio-cultural aspects of historical development, as external, constantly evolving factors, are in quintessence with such well-established internal constituent arts as tradition and language, which accept the new requirements of society and are updated in accordance with the age of society. Therefore, art, as a phenomenon of culture, in artistic forms preserves intrinsic (subjective) and general cultural (objective) features. The identification of culture is not just the identification of values, but rather the materialization of value systems formed on the basis of over-value strategy to overcome the struggle of value systems. It is about the preserving the most valuable cultural features that can preserve and demonstrate to humanity at an affordable level the various stages of the formation of the socio-cultural space.

It is quite logical that there is a certain category that exists in the metaphysical space of being and art, and answers the question of how one or another era is associated with the previous phases of artistic development or appears to be a milestone in consolidating the generalizing artistic whole. It is precisely this category that, in our opinion, is a category of musical ethos of culture.

It should be emphasized that in every cultural-historical epoch one can distinguish the most actual forms of art. At that time one can observe that other types of art tend to this psychological, socio-cultural embodiment in an artistic form by similar means while preserving their own individuality. At the heart of this internal activator lies the 
ethos of culture. But it should be emphasized that human being is viewed from the metaphysical position. And musical art is the only kind of art that fully corresponds to the essence of metaphysics.

The metaphysical power of music is manifested in the form of a musical principle of the image of the essence of World Being and its artistic embodiment in musical forms and objects: "Music on the one hand is cosmic, and on another is subjective: space is musical, but the human soul is also musical" $[3,8]$.

Music reflects the creative power of the Cosmos, it is life in its diversity and organization of chaos. Consequently, in their own sound analogs, music combines the irrationality of chaos and form-forming integrity, and hence the higher systemic harmony. Music appears as a means of exposing the essence of being. Sound itself carries the embodiment of the material and the ideal: reflects the vibration of life. The sphere of sound is universal, and the musical form appears as a socio-cultural fact, in which consciously-immaterial sound can receive some visual and graphic incarnation.

Music is the most vivid and most accessible embodiment of the psychology of social strata of its time and indirectly, through the means of musical expression, and first of all the form, propagates its cultural needs.

So, it's proved the expediency of addressing such opportunities of musical art as the concept of musical ethos. It is considered that the musical ethos in its essence is an intention to the essence of musical life in accordance with the cultural-historical continuum, which reveals the evolution of value orientations of mankind in conditions of infinite space. In the cultural space, musical ethos is a spiritual core, a moral and psychological platform on which the figurative and aesthetic model of contemporary humanity of life and worldview is built. This leads to the actualization of the need to capture the cultural and historical layers of human existence from the point of laconic embodiment in the valuable objects of the artistic cultural industry.

As evidenced by the analysis, the musical ethos reflects the binary nature of our being. In it, as in the musical formation of a higher dimension, the immaterial, temporal and fixed in a particular culture coexist crystalline, which implicitly outlines the basic stages of the formation of the universe and the processual nature of existence. In the musical ethos of culture, one can see the metaphysical essence of music, where there is logic, orderliness of thinking and heuristic presentation. At the same time there is a combination of ideal and material that forms the authentic reflection of the Absolute in the context of the understanding and perception by the humankind of supernatural forces. Against this backdrop, the musical ethos reflects cultural civilization, a society in which there is not only the historical stage of human development, its industrial intentions and possibilities, but above all, everything that is given birth amidst this society, its worldview, its spirit.

The musical ethos gets embodied in artistic forms of culture. These forms represent the sociopsychological orientation of the world image and the general mental setting for the formation of the culturalcivilizational process, its ability to generate and cultivate new types of reactions, ideas, and tastes in these forms. Thus, the musical ethos appears to be the genesis for the implementation in artistic forms of preferences and cultural images.

\section{תimepamypa}

1.Беляев В.А. Кризис интеркультуры и «столкновение цивилизаций». NB: Философские исследования.-2013.-8.-С. 117146. DOI: $10.7256 / 2306-0174.2013 .8 .662$.

2. Кузнецов Ю. В. Мультикультурализм и запрет аргумента ad hominem в научной дискуссии. Философия и культура. 2013, № 4. C. 476-487. DOI: 10.7256/1999-2793.2013.04.6

3.Личковах В. А. Дивосад культури: Вибрані статті з естетики, культурології, філософії мистецтва. Чернігів: РВК «Деснянська правда»,2006. 160 с.

4. Dufrenne M. Phénoménologie de l'expérience esthétique: Thèse. — Paris: Presses univ. de France, 1953. $692 \mathrm{p}$.

5. Harrison L., Huntington S. Culture Matters: How Values Shape Human Progress. — New York: Basic Books, 2000. 320 p.

\section{References}

1.Belyaev V.A. (2013) Krizis interkul'tury i «stolknovenie tsivilizatsii». NB: Filosofskie issledovaniya. DOI: 10.7256/23060174.2013.8.662. [in Russian]

2. Kuznetsov Yu. V. (2013) Multiculturalism and the prohibition of the argument ad hominem in scientific discussion. Philosophy and Culture. Vol.4. p.476-487. DOI: 10.7256/1999-2793.2013.04.6 [in Russian]

3. Lichkovakh V. (2006) Divosad Kultura: Selected articles on aesthetics, cultural studies, philosophy of art. Chernigov: RVC \&quot; Desnianskaya Pravda\&quot;[in Ukrainian].

4. Dufrenne M. (1953) Phénoménologie de l'expérience esthétique: Thèse. — Paris: Presses univ. de France [in Russian]

5. Harrison L., Huntington S. (2000) Culture Matters: How Values Shape Human Progress. New York: Basic Books. [in USA] 